\title{
Population abundance and correlation of sucking insect pests and their natural enemies on different brinjal genotypes
}

\author{
Hafiz Muhammad Faisal Ayub ${ }^{1 *}$, Imtiaz Ali Khan ${ }^{2}$, Amna Sadozai ${ }^{3}$, \\ Jawad Sarwar ${ }^{2}$ and Waheed Ahmad ${ }^{2}$ \\ 1. Agricultural Research Station, Swabi, Swabi-Pakistan \\ 2. Department of Entomology, The University of Agriculture, Peshawar-Pakistan \\ 3. Agricultural Research Institute, Tarnab, Peshawar-Pakistan \\ *Corresponding author's email: faisalayub0007@gmail.com
}

Citation

Hafiz Muhammad Faisal Ayub, Imtiaz Ali Khan, Amna Sadozai, Jawad Sarwar and Waheed Ahmad. Population abundance and correlation of sucking insect pests and their natural enemies on different brinjal genotypes. Pure and Applied Biology. Vol. 9, Issue 1, pp193-201. http://dx.doi.org/10.19045/bspab.2020.90023

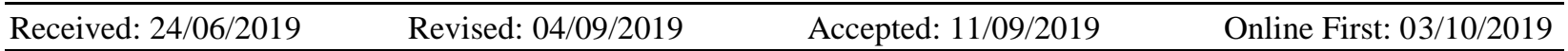

\section{Abstract}

To screen out the resistant brinjal genotype and to identify effective natural enemies of the sucking insect pests of brinjal an organic experiment was carried out in the Entomology Section, Agricultural Research Institute, Tarnab - Peshawar during 2016. Five brinjal genotypes namely Shamli hybrid, Local long, Black neelum, Local round and Purple long were tested. The experiment followed a randomized complete block design (RCBD) with three replications. Weekly data were recorded on the population densities of insect pests i.e. brinjal aphid, brinjal jassid, whitefly and natural enemies i.e. ladybird beetle and green lacewings. Results revealed that the overall mean density of brinjal aphid and brinjal jassid was significantly higher on genotype Local round, i.e. 4.89 and 4.68 individuals leaf $^{-1}$ while significantly lower on Shamli hybrid i.e. 3.07 and 0.68 individuals leaf $^{-1}$, respectively. A Significantly higher overall mean density of whitefly was recorded on genotype Local round (10.30 individuals leaf ${ }^{-1}$ ) while lower was recorded on Shamli hybrid (7.20 individuals leaf ${ }^{-1}$ ). The overall mean density of ladybird beetle and green lacewings was significantly higher on genotype Shamli hybrid, i.e. 1.96 and 2.96 individual leaf ${ }^{-1}$ whereas significantly lower on Local

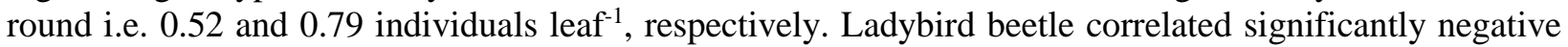
with brinjal aphid and brinjal jassid whereas green lacewings showed a significant and positive correlation with brinjal aphid and whitefly hence, the use of a resistive genotype and natural enemies may be incorporated in an integrated pest management (IPM) program against sucking insect pests.

Keywords: Aphis gossypii; Coccinella septempunctata; Integrated pest management (IPM);

Shamli hybrid

\section{Introduction}

Brinjal or Eggplant (Solanum melongena L.), also known as Aubergine (French word), is the world's one of the top ten vegetables [1]. This vegetable of family Solanaceae is an important and popular crop of the tropical and subtropical climatic zone of the world [2].
Asia is producing about 92 percent of the world's brinjal, accounting for approximately 94 percent of the world brinjal area [3]. For brinjal cultivation, Pakistan accounts for 9,044 ha area, resulting in 88,148 tons' production annually [4]. It is producing 97,466 kg brinjal per hectare [5]. The production of the brinjal crop in Pakistan is 
fair enough, but in comparison to that of the rest of the world's countries, it is very low. It is damaged by many insect pests at different intervals of its development until harvesting, thus resulting in its lower production $[6,7]$. Some of the substantial insect pests of brinjal in Pakistan include brinjal fruit borer, brinjal stem borer, brinjal aphid, brinjal jassid, whitefly and thrips, etc. [1].

Brinjal aphid, Aphis gossypii Glover (Hemiptera: Aphididae) is a polyphagous pest. Both the nymphs and adults present in abundance on the young shoots and underside of the leaf surfaces and suck the plant's cell sap. In the case of slight infestation leaves exhibit yellowing while in severe infestation the young leaves curl and deform occurs. They also produce honeydews, leading to the development of sooty mold fungi, thus cause hindrance in the process of photosynthesis [1]. Brinjal jassid, Amrasca biguttula biguttula Ishida (Hemiptera: Cicadellidae) is another important pest in Pakistan [8]. Both adults and nymphs of jassid occur on the lower leaf surfaces and feed by sucking the plant's cell sap resulting in curling and yellowing of leaves [9]. Whitefly, Bemisia tabaci Gennadius (Hemiptera: Aleyrodidae) is also an important pest of brinjal however it is highly polyphagous. Both adults and nymphs of the whitefly suck the plant sap which reduces the plant's vigor. Yellowing and dropping off of the plant leaves are the symptoms of severe infestation related to this insect pest. It is a diurnal insect and rests on the lower leaf surfaces during the night [1]. Plants are unable to escape their enemies, that is, the pests that may feed on them. Therefore, under certain conditions, they depend upon the natural enemies of those herbivore insects for their defense. These natural enemies may be predators and parasitoids [10]. Coccinellid Beetles are the important predators that play a vital part in the suppression of insect pests in nature [11].
Aphid lion, Chrysoperla carnea Stephens (Neuroptera: Chrysopidae) is also one of the widespread and most generalist predator insect used insect pest management programs [12].

To control those insect pests, most of the growing community, mainly depends upon haphazard and injudicious use of different chemicals. Excessive use of these chemicals on the crop not only adversely affects the environment and human health, but also affects the natural enemies of those insect pests and increases the cost of production as well, making it expensive for consumers [13]. Host plant resistance alone or in combination with other methods are environmentally safe and compatible with IPM [14]. The selection of resistant cultivars against the insect pests of the crop is a vital approach of integrated pest management [15].

Keeping in view the importance of resistant genotypes and the aforesaid information the current experiment is carried out to screen out different brinjal genotypes versus sucking insect pests to identify the resistant brinjal genotype as well as to correlate them with their natural enemies, which in return will help out the farmers for cultivating this important vegetable and will also increase its yield with less or without the use of chemicals.

\section{Materials and methods \\ Experimental layout}

The experiment was carried out in the Entomology Section, Agricultural Research Institute (ARI), Tarnab. Seedlings of brinjal genotypes viz. Local Round, Local Long, Shamli Hybrid, Black Neelum and Purple Long were purchased from the local market of Tarnab, Peshawar. Seedlings were transplanted on $7^{\text {th }}$ March 2016 on ridges in randomized complete block design (RCBD) with three replications each comprised of five plots. Row to row distance was kept at $75 \mathrm{~cm}$ while plant to plant distance was kept at 45 
$\mathrm{cm}$. There were two rows of 14 plants each per treatment. The size of each plot was $6 \times 3$ $\mathrm{m}^{2}$. The treatments and replication were isolated from each other by a non - cropped area of $2 \mathrm{ft}$ and $3 \mathrm{ft}$, respectively. Standard and uniform agronomic practices including irrigation, hoeing, ploughing and weeding, etc. were followed during the cropping season in each treatment.

\section{Population abundance of insects}

Insect pests scouting were performed regularly every week. A sampling of foliage insect pests and their associated natural enemies were started from the first appearance of insects till the maturity of the crop. Data were recorded from 07 to 10 am every week. Five plants of each genotype were selected randomly and the population of aphids, jassids, whitefly, ladybird beetle green lacewings was recorded on three leaves, i.e., one each from the top, middle and bottom canopy of the brinjal plants in the field. The data were converted into means of nymphs and adults.

\section{Statistical analysis}

The data collected was then subjected to statistical analysis through the Statistical Program of Statistix 8.1 and the Least Significant Difference (LSD) test at a 5\% level of significance was used to separate the means [16].

\section{Results and discussion}

A single species, each of aphids, jassids and whiteflies were identified attacking the brinjal crop, namely Aphis gossypii Glover (Hemiptera: Aphididae), Amrasca biguttula biguttula Ishida (Hemiptera: Cicadellidae) and Bemisia tabaci Gennadius (Hemiptera: Aleyrodidae) respectively. Among the natural enemies, one species, each of ladybird beetle and green lacewings were identified, i.e. Coccinella septempunctata Linnaeus (Coleoptera: Coccinellidae) and Chrysoperla carnea Stephens (Neuroptera: Chrysopidae) respectively. Same insect pests were recorded on different brinjal genotypes by some earlier researchers, i.e. [17] identified and recorded Aphis gossypii, Amrasca biguttula biguttula and Leucinodes orbonalis on different brinjal genotypes. [18] Recorded natural enemies namely, Coccinella septempunctata and Chrysoperla carnea on brinjal genotypes against insect pests. [19] Recorded the population dynamics of whiteflies, Bemisia tabaci Gennadius (Hemiptera: Aleyrodidae) on brinjal crop.

\section{Insect pests}

Brinjal aphid, Aphis gossypii (Glover)

The results revealed that the mean density of Aphis gossypii leaf ${ }^{-1}$ varied significantly on different brinjal genotypes (Table 1). The overall mean density of A. gossypii leaf ${ }^{-1}$ was significantly higher on Local round (4.89 leaf ${ }^{-1}$ ) while significantly lower on Shamli hybrid $\left(3.07 \mathrm{leaf}^{-1}\right)$. It was found that the mean weekly density of $A$. gossypii leaf ${ }^{-1}$ was significantly higher on Local round throughout the period while lower on genotype Shamli hybrid throughout with an exception to genotype Local long where it was lower on $16^{\text {th }}$ May (6.10 leaf $\left.^{-1}\right)$. Our results are comparable to those of $[17,20]$. [17] Observed aphid infestation three weeks after transplanting and also recorded the highest infestation in the mid-week of May (5.33 aphid leaf $^{-1}$ ). [20] Recorded aphid infestation on brinjal from the beginning of crop till the maturity. They found a higher population of aphids in May (2.07 aphids leaf $^{-1}$ ), which decreased till the mid-June (1.30 aphids leaf $\left.{ }^{-1}\right)$.

\section{Brinjal jassid, Amrasca biguttula biguttula (Ishida)}

The overall mean density of A. biguttula biguttula per leaf varied significantly among the five brinjal genotypes (Table 2). A significantly higher infestation of the pest was observed on the genotype Local round (4.68 individuals per leaf) while significantly lower infestation was recorded on the genotype Shamli hybrid (0.68 individuals per 
leaf). The results of the mean weekly density of A. biguttula biguttula per leaf showed that significantly higher mean density of jassid per leaf was recorded on the genotype Local round while the significantly lower mean density of the pest individuals per leaf was recorded on genotype Shamli hybrid throughout the period. [21] Stated that the infestation initiated in April $( \pm 0.4$ jassids per leaf) reached to the climax in May $( \pm 4$ jassids per leaf) and then declined gradually till June ( \pm 1 jassids per leaf). [8] Also presented a similar type of results. They stated that the jassids' population was found as positively correlated with minimum and maximum temperature while negatively correlated with the rainfall. Our results are incongruous with that of the [5] who carried out their experiment in November and December i.e. the cooler months of the year. The reason for this disagreement in the trend of population abundance might be the seasonal difference.

\section{Whitefly, Bemisia tabaci (Gennadius)}

It is evident from the data that the overall mean density of $B$. tabaci also differed significantly among the brinjal genotypes screened. Statistical analysis revealed that the overall mean density of $B$. tabaci was significantly higher on genotype Local round with 10.30 individual's leaf ${ }^{-1}$ while lower on Shamli hybrid with 7.20 individual's leaf $^{-1}$ (Table 3). Higher infestation by B. tabaci was observed on the genotype Local round while lower infestation was observed in general on genotype Shamli hybrid throughout the study. On $25^{\text {th }}$ April, $2^{\text {nd }}$ May, $9^{\text {th }}$ May, $23^{\text {rd }}$ May and $30^{\text {th }}$ May lower infestation were recorded on genotype Purple long having $6.39,6.23,7.48,12.95$ and 6.66 individuals leaf $^{-1}$ respectively. These findings are justified by [22] who stated that whitefly appeared the first week after transplanting and persisted throughout the season. [23] Listed whitefly among the common and major insect pests of brinjal. [20] Reported that Maximum and minimum temperature have a positive correlation while relative humidity and rainfall have a negative correlation with the whitefly population. 
Table 1. Mean density of Aphis gossypii leaf ${ }^{-1}$ on five different brinjal genotypes in Tarnab-Peshawar during 2016

\begin{tabular}{|c|c|c|c|c|c|c|c|c|c|}
\hline \multirow{2}{*}{ Genotype } & \multicolumn{8}{|c|}{ Mean density of Aphis gossypii leaf ${ }^{-1}$ on } & \multirow{2}{*}{ Overall Mean } \\
\hline & $25^{\text {th }} \mathrm{Apr}$ & $2^{\text {nd }}$ May & $9^{\text {th }}$ May & $16^{\text {th }}$ May & $\mathbf{2 3}^{\text {rd }}$ May & 30 ${ }^{\text {th }}$ May & 6 $^{\text {th }}$ Jun & $13^{\text {th }}$ Jun & \\
\hline Shamli Hybrid & 0.63 & 3.10 & 4.12 & 6.39 & 6.27 & 2.46 & 1.27 & 0.37 & 3.07 a \\
\hline Local Long & 1.31 & 4.34 & 5.49 & 6.10 & 6.30 & 3.37 & 2.49 & 1.48 & $3.86 \mathrm{~b}$ \\
\hline Black Neelum & 1.60 & 4.35 & 5.37 & 6.24 & 6.33 & 3.23 & 2.37 & 1.39 & $3.86 \mathrm{~b}$ \\
\hline Local Round & 2.11 & 5.93 & 6.47 & 7.69 & 7.36 & 4.47 & 3.22 & 1.91 & $4.89 \mathrm{c}$ \\
\hline Purple long & 1.51 & 4.61 & 5.45 & 6.21 & 6.50 & 3.47 & 2.25 & 1.50 & $3.93 \mathrm{~b}$ \\
\hline
\end{tabular}

Means within the last column followed by different letters are significantly different at 5\% level of significance (LSD test)

LSD value for Genotypes $=0.2099$

$\mathrm{CV}=9.38 \%$

Table 2. Mean density of Amrasca biguttula biguttula leaf ${ }^{-1}$ on five different brinjal genotypes in Tarnab-Peshawar during 2016

\begin{tabular}{|c|c|c|c|c|c|c|c|c|c|}
\hline \multirow{2}{*}{ Genotype } & \multicolumn{8}{|c|}{ Mean density of Amrasca biguttula biguttula leaf $^{-1}$ on } & \multirow{2}{*}{ Overall Mean } \\
\hline & $25^{\text {th }} \mathrm{Apr}$ & $2^{\text {nd }}$ May & $9^{\text {th }}$ May & $16^{\text {th }}$ May & $23^{\text {rd }}$ May & 30 ${ }^{\text {th }}$ May & $6^{\text {th }}$ Jun & $13^{\text {th }} \mathrm{Jun}$ & \\
\hline Shamli Hybrid & 0.13 & 0.07 & 0.60 & 0.87 & 1.20 & 1.24 & 1.05 & 0.37 & $0.68 \mathrm{e}$ \\
\hline Local Long & 1.34 & 1.63 & 2.24 & 3.73 & 4.01 & 2.44 & 2.49 & 1.38 & $2.40 \mathrm{~d}$ \\
\hline Black Neelum & 1.54 & 1.27 & 1.94 & 4.61 & 4.21 & 3.27 & 2.15 & 2.23 & $2.65 \mathrm{c}$ \\
\hline Local Round & 3.03 & 3.37 & 3.63 & 6.93 & 7.41 & 4.92 & 4.31 & 3.87 & $4.68 \mathrm{a}$ \\
\hline Purple Long & 2.01 & 2.33 & 2.14 & 4.91 & 4.13 & 2.68 & 3.04 & 1.33 & $2.82 \mathrm{~b}$ \\
\hline
\end{tabular}

Means within the last column followed by different letters are significantly different at $5 \%$ level of significance (LSD test)

LSD value for Genotypes $=0.2266$

$\mathrm{CV}=14.87 \%$

Table 3. Mean density of Bemisia tabaci leaf ${ }^{-1}$ on five different brinjal genotypes in Tarnab-Peshawar during 2016

\begin{tabular}{|c|c|c|c|c|c|c|c|c|c|}
\hline \multirow[b]{2}{*}{ Genotype } & \multicolumn{8}{|c|}{ Mean density of Bemisia tabaci leaf ${ }^{-1}$ on } & \multirow[b]{2}{*}{ Overall Mean } \\
\hline & $2^{\text {th }} \mathrm{Apr}$ & $2^{\text {nd }}$ May & $9^{\text {th }}$ May & 16 $^{\text {th }}$ May & $\mathbf{2 3}^{\text {rd }}$ May & 30 ${ }^{\text {th }}$ May & $6^{\text {th }}$ Jun & 13th Jun & \\
\hline Shamli Hybrid & 6.40 & 6.25 & 7.59 & 10.24 & 13.21 & 9.19 & 4.14 & 0.62 & $7.20 \mathrm{c}$ \\
\hline Local Long & 7.18 & 7.81 & 8.40 & 12.53 & 13.55 & 9.43 & 5.49 & 2.02 & $8.30 \mathrm{~b}$ \\
\hline Black Neelum & 7.23 & 7.18 & 7.04 & 12.20 & 17.15 & 9.72 & 5.38 & 2.13 & $8.50 \mathrm{~b}$ \\
\hline Local Round & 8.12 & 8.23 & 10.34 & 15.06 & 20.18 & 10.31 & 6.48 & 3.72 & 10.30 a \\
\hline Purple Long & 6.39 & 6.23 & 7.48 & 11.66 & 12.95 & 6.66 & 5.46 & 2.08 & $7.36 \mathrm{c}$ \\
\hline
\end{tabular}

Means within the last column followed by different letters are significantly different at $5 \%$ level of significance (LSD test)

LSD value for Genotypes $=0.6456$

$\mathrm{CV}=13.47 \%$ 
Natural enemies

Ladybird Beetle, Coccinella septempunctata (Linnaeus)

All the five brinjal genotypes differed highly significant in the overall mean abundance of C. septempunctata (Table 4). Statistical analysis revealed that a significantly higher abundance of $C$. septempunctata was found in genotype Shamli hybrid (1.96 per leaf) while significantly lower abundance was found on Local round (0.52 per leaf).It is noted that significantly higher mean weekly abundance of $C$. septempunctata was found in genotype Shamli hybrid and Lower $C$. septempunctata abundance was found on Local round throughout the cropping season except $2^{\text {nd }}$ May where lower abundance was noted on genotype Purple long (0.32 per leaf).The $C$. septempunctata appeared on $25^{\text {th }}$ April and its abundance was more or less consistent during the whole cropping season till $13^{\text {th }}$ June. Our results are comparable to those of [18] whom recorded comparatively higher mean density of beetle on genotype Shamli hybrid (0.79 per leaf) moreover they also observed the ups and downs throughout their study. [11] Found the beetle active throughout the study period on brinjal in 2005, 2006 and 2007. They stated that the beetle had a significant positive correlation with the mean and maximum temperature, whereas it had a significant negative correlation with the rainfall which justified our pattern of beetle abundance.

Green lacewings, Chrysoperla carnea (Stephens)

The overall mean density of $C$. carnea also varied highly significantly among the five brinjal genotypes (Table 5). It was recorded significantly higher on Shamli hybrid with an overall mean density of 2.96 individual's leaf ${ }^{-1}$ while significantly lower density was recorded on genotype Local round with 0.79 individuals leaf ${ }^{-1}$. The mean weekly density of $C$. carnea on brinjal genotypes is presented by Figure 6. The higher mean density of $C$. carnea was recorded on Shamli hybrid throughout the study. In general, the lower mean density of $C$. carnea was observed on the genotype Local round while lower mean density was recorded on genotype Local long with 0.41 individual's leaf $^{-1}$ and on Purple long with 0.34 individual's leaf ${ }^{-1}$ on $25^{\text {th }}$ April and $13^{\text {th }}$ June respectively. [18] Also reported comparatively higher density of green lacewings on genotype Shamli hybrid $(0.44$ individual's leaf $\left.{ }^{-1}\right)$. Also, a similar trend of population density was observed by them.

Correlation of insect pests and natural enemies on brinjal genotypes

Correlation between insect pests and ladybird beetle

It is revealed that aphids exhibit a significant negative correlation with ladybird beetle. Jassids also had a significant negative correlation with the ladybird beetle while whitefly showed a non-significant negative correlation with the ladybird beetle (Table 6). [24] Who reported that the aphid population decreased with an increase in the population of ladybird beetle. [25] Stated that the predation rate of ladybird beetle increased with an increase in the prey population i.e. jassids. [26] Stated that all the ladybird beetle species had a higher preference for whitefly immature ones with a consumption rate of 3 nymphs after 24 hours. 
Table 4. Mean density of Coccinella septempunctataleaf ${ }^{-1}$ on five different brinjal genotypes in Tarnab - Peshawar during 2016

\begin{tabular}{|c|c|c|c|c|c|c|c|c|c|}
\hline \multirow[b]{2}{*}{ Genotype } & \multicolumn{8}{|c|}{ Mean density of Coccinella septempunctata leaf $^{-1}$ on } & \multirow[b]{2}{*}{ Overall Mean } \\
\hline & $25^{\text {th }} \mathrm{Apr}$ & $2^{\text {nd }}$ May & $9^{\text {th }}$ May & $16^{\text {th }}$ May & $23^{\text {rd }}$ May & 30 $^{\text {th }}$ May & 6 $^{\text {th }}$ Jun & 13th Jun & \\
\hline Shamli Hybrid & 1.91 & 1.82 & 1.98 & 2.01 & 2.02 & 1.98 & 2.01 & 1.99 & $1.96 \mathrm{a}$ \\
\hline Local Long & 0.57 & 1.08 & 0.48 & 0.56 & 0.52 & 0.78 & 0.67 & 0.62 & $0.66 \mathrm{~d}$ \\
\hline Black Neelum & 1.29 & 1.06 & 1.33 & 1.43 & 1.49 & 1.23 & 1.46 & 1.45 & $1.34 \mathrm{~b}$ \\
\hline Local Round & 0.56 & 0.55 & 0.47 & 0.51 & 0.50 & 0.56 & 0.49 & 0.53 & $0.52 \mathrm{e}$ \\
\hline Purple Long & 1.39 & 0.32 & 0.75 & 0.64 & 0.90 & 1.49 & 1.12 & 1.13 & 0.97 c \\
\hline
\end{tabular}

Means within the last column followed by different letters are significantly different at $5 \%$ level of significance (LSD test)

LSD value for Genotypes $=0.1082$

$\mathrm{CV}=17.20 \%$

Table 5. Mean density of Chrysoperla carnealeaf ${ }^{-1}$ on five different brinjal genotypes in Tarnab-Peshawar during 2016.

\begin{tabular}{|c|c|c|c|c|c|c|c|c|c|}
\hline \multirow{2}{*}{ Genotype } & \multicolumn{8}{|c|}{ Mean density of Chrysoperla carnea leaf $^{-1}$ on } & \multirow{2}{*}{ Overall Mean } \\
\hline & $25^{\text {th }} \mathrm{Apr}$ & $2^{\text {nd }}$ May & $9^{\text {th }}$ May & $1^{\text {th }}$ May & $23^{\text {rd }}$ May & 30 $^{\text {th }}$ May & 6 $^{\text {th }}$ Jun & 13th Jun & \\
\hline Shamli Hybrid & 1.96 & 2.03 & 3.82 & 6.04 & 3.97 & 2.01 & 2.04 & 1.84 & $2.96 \mathrm{a}$ \\
\hline Local Long & 0.41 & 0.59 & 1.15 & 2.01 & 1.57 & 0.64 & 0.54 & 1.10 & $0.99 \mathrm{~d}$ \\
\hline Black Neelum & 1.31 & 1.45 & 2.59 & 4.40 & 2.46 & 1.47 & 1.51 & 1.08 & $2.03 \mathrm{~b}$ \\
\hline Local Round & 0.45 & 0.53 & 1.12 & 1.49 & 1.12 & 0.55 & 0.52 & 0.57 & $0.79 \mathrm{e}$ \\
\hline Purple Long & 0.73 & 0.66 & 2.78 & 3.37 & 2.98 & 1.15 & 1.14 & 0.34 & $1.64 \mathrm{c}$ \\
\hline
\end{tabular}

Means within the last column followed by different letters are significantly different at 5\% level of significance (LSD test)

LSD value for Genotypes $=0.1613$

$\mathrm{CV}=16.62 \%$

Table 6. Correlation between insect pests and their associated natural enemies during2016

\begin{tabular}{|c|c|c|c|}
\hline \multirow{2}{*}{ Natural Enemies } & \multicolumn{3}{|c|}{ Insect Pests } \\
\cline { 2 - 4 } & Aphids & Jassids & Whitefly \\
\hline Ladybird Beetle & $-0.2896^{*}$ & $-0.5713^{*}$ & $-0.1662 \mathrm{~ns}$ \\
\hline Green Lacewings & $0.4171^{*}$ & $-0.1163 \mathrm{~ns}$ & $0.3078^{*}$ \\
\hline
\end{tabular}

*Significant at a 5\% level of significance

Ns Non-significant 


\section{Correlation between insect pests and green lacewings}

Aphid showed a significant positive correlation with Green lacewings. Jassids had a non-significant negative correlation with green lacewings whereas whitefly showed a significant positive correlation with green lacewings (Table 6). [27] Concluded that green lacewings during its whole life consumed $36.6 \pm 0.92$ jassids. Furthermore [28] stated that green lacewings is a voracious eater of many soft-bodied insect pests and their eggs including jassids. Our correlation study between whitefly and lacewings is supported by the work of [29] stated that the release of green lacewings larvae under semi-field conditions causes a reduction in immature ones of whitefly.

\section{Conclusion}

It can be concluded that a high population of insect pests was recorded on the genotype Local round while the lower was recorded on Shamli hybrid, hence declared resistive genotype and recommended for cultivation. Moreover, the correlation showed that the use of natural enemies was found to be a good strategy and can be used in integrated pest management (IPM) program against sucking insect pests. Studies on physio-morphic plant characters and the proximate chemical composition should be done. Research on the predation rate of these predators, both in the laboratory as well as in field conditions needs to be carried out to successfully integrate them into IPM programs.

\section{Author's contributions}

Conceived and designed the experiments: IA Khan, Performed the experiments HMF Ayub, Analyzed the data: A Sadozai, Contributed reagents/ materials/ analysis tools: J Sarwar \& W Ahmad, Wrote the paper: HMF Ayub.

\section{References}

1. Srinivasan R (2009). Insect and mite pests on eggplant: a field guide for identification and management. AVRDC - The World
Vegetable Center, Shanhua, Taiwan. AVRDC Publication No. 09-729. pp 64.

2. Anonymous (2010). Biology of Brinjal. Ministry of Environment and Forestry and Department of Biotech., Ministry of Sci. and Tech., Govt. of India. pp 27.

3. FAO (2007). FAOSTAT. (http://faostat.fao.org). [Accessed 30 ${ }^{\text {th }}$ July 2016].

4. FAO (2012). FAOSTAT. Eggplant Statistics. 2010. Statistical Division, Food and Agriculture Organization of the United Nations.

5. Yousafi Q, Afzal M, Aslam M, Razaq M \& Shahid M (2013). Screening of Brinjal (Solanum melongena L.) Varieties Sown in autumn for Resistance to Cotton Jassid Amrasca biguttula biguttula (Ishida). Pak J Zool 45(4): 897-902.

6. Dhamdhere S, Dhamdhere SV \& Matur R (1995). Occurrence and succession of pests of brinjal, Solanum melongena L. at Gwalior (M.P.), Ind J Entomol Res 19: 71-77.

7. Roy DC \& Pande YD (1995). Damage to brinjal by Lep. Pyraustidae and economics of its insecticidal control. Ind J Agric Res 28: 110-120.

8. Mahmood T, Hussain SI, Khokhar KM, Hidayatullah \& Jeelani G (2002). Varietal resistance in eggplant to cotton jassid (Amrasca biguttula biguttula). Asi J Pl Sci 1(4): 107-108.

9. Rahman MM, Rahman MM \& Ali MR (2009). Evaluation of some selected options for managing brinjal shoot and fruit borer in two intensive brinjal growing areas. World $J$ Zool 4: 169-175.

10. Rodriguez-Saona $\mathrm{C}, \mathrm{Blaauw} \mathrm{BR} \&$ Isaacs $\mathrm{R}$ (2012). Manipulation of natural enemies in Agro-ecosystems: Habitat and Samiochemicals for sustainable insect pest control. Integrated Pest Management and Pest Control - Current and Future Tactics. pp 89126.

11. Ghosh SKR \& Chakraborty K (2012). Incidence and abundance of important predatory beetles with special reference to Coccinella septempunctata in SubHimalayan region of North-East India. Intern J Pl Anim Envir Sci 2(3): 157-162. 
12. Athhan R, Kaydan B \& Ozogokce MS (2004). Feeding activity and life history characteristics of the generalist predator, Chrysoperla carnea (Neuroptera: Chrysopidae) at different prey densities. $J$ Pest Sci 77: 17-21.

13. Ali M, Ashfaq M, Rana N, Haider MS, Ashfaq M \& Amjad M (2014). The susceptibility study of some Aubergine (Solanum melongena L.) cultivars against Jassid (Amrasca biguttula biguttula (Ishida). Pak J Agri Sci 51(3): 679-683.

14. Srivastava KP (1993). Chemical control of insect pest complex of brinjal. Entomon 8: 97-100.

15. Bhatti MA, Saeed M, Chatta N \& Iqbal S (1976). Host plant resistance and importance to insect population suppression in cotton crop. Proc. Cott. Prod. Seminar, ESSO, Pak. Fertilizer Co. Ltd. pp 132-142.

16. Steel RGD \& Torrie JH (1980). Principals and procedures of statistics: A biological approach. $2^{\text {nd }}$ Ed. McGraw Hill Book Co. New York. pp 481.

17. Habib K, Khan IA, Akbar R, Khan A, Saeed M, Farid A, Ali I \& Alam M (2015). Response of Brinjal, Solanum melongena L. (Solanales: Solanaceae), Genotypes against Insect Pests in Peshawar. Pak J Entomol Zool Stud 3(3): 423-427.

18. Khan IA, Habib K, Akbar R, Khan A, Saeed A, Farid A, Ali I \& Alam M (2015) Proximate chemical composition of brinjal, Solanum melongena L. (Solanales: Solanaceae), genotypes and its Correlation with the insect pests in Peshawar. J Entomol Zool Stud 3(4): 303-306.

19. Mane PD \& Kulkarni SN (2011). Population dynamics of white flies, BemisiatabaciGenn. onbrinjal. Int $\mathrm{J} P \mathrm{Pl}$ Protec 4(1): 140-142.

20. Patel HV, Radadia GG \& Chavda SK (2015). Seasonal incidence of major insect pests of brinjal crop during summer season. Insect Envir 20(4): 149-151.

21. Ali M, Ashfaq M, Ranjha MH, Gulzar A, Ahmad S \& Ali A (2016). The host plant susceptibility indices and varietal preference of jassid (Amrasca bigutulla bigutulla
Ishida) on eggplant (Solanum melongena L.) in Punjab Pakistan. Pak Entomol 38(1): 1518.

22. Muthukumar $M$ \& Kalyanasundaram (2003). Influence of abiotic factors on the incidence of major insect pests in brinjal (Solanum melongena L.). South Ind Horticul 51(1/6): 214-218.

23. Latif MA, Rahman MM, Islam MR \& Nuruddin MM (2009). Survey of arthropod biodiversity in the brinjal field. $J$ Entomol 6(1): 28-34.

24. Ashfaq M, Hassan M, Salman B, Salman W \& Rana N (2007). Some studies on the efficiency of Chrysoperla carnea against aphid, Brevicoryne brassicae, infesting canola. Pak Entomol 29(1): 37-41.

25. Inayat $\mathrm{TP}$, Rana $\mathrm{SA}$, Rana $\mathrm{N}$, Ruby $\mathrm{T}$, Sadiqui MJI \& Abbas MN (2011). Predation rate in selected coccinellid (coleoptera) predators on some major aphidid and cicadellid (Hemipteran) pests. Int J Agric Biol 13: 427-430.

26. Atuncha H, Ateka E, Amata R, Mwirichia R, Kasina M, Mbevi B \& Wakoli E (2013). Evaluation of predation potential of coccinellids on cassava whiteflies. $J$ Entomol Nematol 5(7): 84-87.

27. Bukero A, Lanjar AG, Solangi AW, Talpur MA, Nizamani and SA \& Khuhro SA (2014). Feeding potential and larval development of Chrysoperla carnea (stephen) on different prey species under laboratory condition. Sci Int (Lahore) 26(4): 1465-1470.

28. Farid A, Usman A \& Khattak SUK (2006). Effect of different artificial diets on the biology of adult green lacewing, Chrysoperla carnea (Stephens). J Sci Technol 28(1): 1-8.

29. Younes MWF, Shoukry IF, Metwally SAG \& Abd-Allah YNM (2013). Efficiency of second instar larvae of Chrysoperla carnea to suppress some piercing sucking insects infesting cantaloupe under semi- field conditions. Egypt J Agric Res 91(1): 169178. 